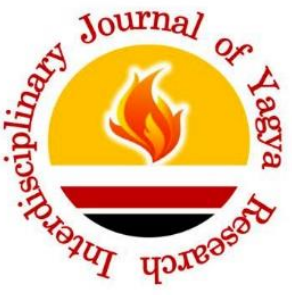

INTERDISCIPLINARY JOURNAL OF YAGYA RESEARCH

Peer Reviewed Research Journal

VOLUME 1 ISSUE 1

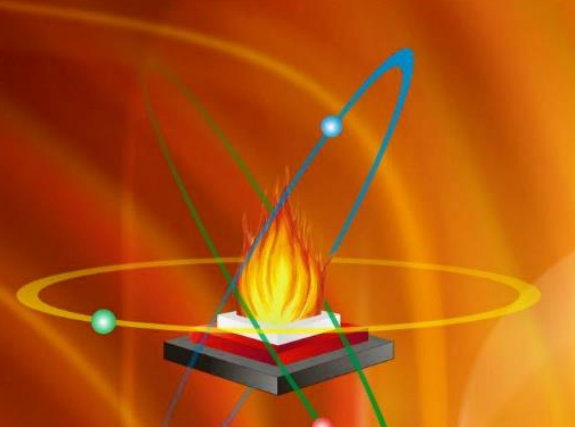

8 


\title{
Yagya Therapy in Vedic and Ayurvedic Literature: A Preliminary exploration
}

\author{
Shilpi Verma ${ }^{1}$, Alka Mishra $^{2 *}$, Vandana Shrivastava ${ }^{3}$ \\ ${ }^{1}$ Office Assistant, Centre for Distance Education, Dev Sanskriti Vishwavidyalaya, Haridwar \\ ${ }^{2}$ Assistant Professor, Department of Yoga and Health, Dev Sanskriti Vishwavidyalaya, Haridwar \\ ${ }^{3}$ Associate Professor, Department of Yoga and Health, Dev Sanskriti Vishwavidyalaya, Haridwar \\ * Corresponding author: Alka Mishra. Email: alka.mishra@dsvv.ac.in
}

\begin{abstract}
There is ample description of Yagya in Vedic literature that refers to its multiple applications such as social development, spiritual development, ecological balance, and preventing and curing diseases. Among them, one important aspect is health. Therapeutic application of Yagya is known as Yagya Therapy or Yagyopathy. In India, people perform Yagya for various reasons and knowingly and unknowingly utilize Yagya as therapy. However, its root-knowledge is not known to them. Hence, it is necessary to find the original references of Yagya Therapy from Vedic and Ayurvedic texts, which will not only strengthen its conceptual understanding, but will also make the basis for public benefit, as well as for further research. Here, the presented study took
\end{abstract}

narrative literature survey approach. The study attempted to shed light on Yagya Therapy using the descriptions from Vedic and Ayurvedic literature. It has been observed that Vedic literature describes treatment of wide range of diseases (both infectious and non-infectious) and ailments through Yagya, along with the precautions, detailed procedures, causes of diseases, therapeutic supplements, etc. Thus, this study will help in the establishment of Yagya Therapy as an important therapeutic approach, and will pave the way for further investigations in this field.

Keywords. Yagya Therapy, Veda, Ayurveda, Diseases, Medicinal herbal smoke 


\section{Introduction}

The main subject of Vedic literature is Yagya. Vedas are full of descriptions of Yagya (1). Yagya has multiple applications described in Vedic and Ayurvedic literature. For instance, Yagya has been used in solving the problems related to environment, in managing natural disasters, for achieving spiritual progress, for maintaining ecological balance, for managing social and political balance, and for preventing and curing diseases (2).

Since Vedic era, application of Yagya for health benefit is one of the important utility of Yagya. In the Vedic era, Yagya was widely used for preventing and curing various diseases and ailments, and also for improving and maintaining immunity for individuals, as well as for masses (3). In Vedic era, Yagya Therapy had been developed into a sophisticated therapeutic system. During Vedic time, Gurukuls and Aaranyaks served the purpose of hospitals, where Yagya was primary mode of therapy for successful treatment of diseases and ailments. Moreover, procedures and applications were very precise and advanced. For example, application of Yagya Therapy included

Besides Vedic literature, Ayurvedic literature also describes use of medicinal-smoke as therapy, which is a similar concept to that of Bheshaj Yagya. Maharshi Charak also referred Yagya as therapy (Charak Samhita 1/15/56). This is also supported with the notion that Ayurveda is considered as sub-field (Upaang) of Atharvaveda (Sushrut Samhita 1/1/5) (4); hence, it is expected that Ayurvedic literature might have also described the utility of some form of Yagya. In Ayurvedic literature, method of medicinal-smoke inhalation for therapy is referred with names such as DhoomNasya or Dhoomapana (5).

Yagya is an important part of Vedic and Ayurvedic literature, and its utility in different traditions and parts of India is still observed carrying remnants of Vedic traditions (Brahmavarchas, 1994b). Today, through worshiping and rituals such as house warming, wedding, baby-shower, annaprashan, tonsure (mundan) and other sanskars, Yagya is applied specific hawan-samagri (herbs), specific-samidhas (wood materials), specific type of animal's ghrit (clarified butter made out of specific animals' milk), specific-rituals including specified mantras, shapessizes of kunds, and specific time of the Yagya performance, etc., which varied according to disease types and patients' conditions. Vedic references indicated that Yagya Therapy was very advanced at that stage, however, in due course, the fine details of these protocols and applications were lost (6).

The concept of burning herbs in the fire to generate medicinal-smoke and taking it through breath by performing pranayama prevails in the Vedic literature. The Yagya, which includes the application of herbs, is known as Bheshaj Yagya. Even in modern time, application of Bheshaj Yagya is commonly seen in Indian culture (7). Based on this concept, Yagya Therapy or Yagyopathy was defined for the present study as an ancient Indian therapeutic procedure of herbal pulmonary inhalation allowing administration of medicinal-smoke of specific herbs generated through sacrifice in specific-fire-environment (8),

for health benefits knowingly or unknowingly. However, for its proper utilization and awareness for mass applications, it is necessary to find the original references from Vedic and Ayurvedic texts regarding Yagya as a therapeutic application. This will not only strengthen its conceptual understanding in the society, but will also make the basis for further research. The present study attempted to shed light on Yagya Therapy for various diseases by reviewing descriptions from Vedic, Ayurvedic and their supporting literature.

\section{Methods}

The study took the approach of narrative literature review, researching Vedic and Ayurvedic literature, with special reference to Pt. Shriram Sharma Acharya Vangmay (complete works).

\section{Results and Discussion}

General description of management of various diseases through Yagya Therapy in Vedic literature 
Yagya Therapy in Vedic scripture has described treatment of various physiological, psychological, emotional and spiritual ailments, and diseases (9). For instance, Rigveda 3/10/3 mentioned general health benefits through divine Yagya fire obligations of various herbs to be strengthened and nurtured (10). Atharvaveda 3/11/1-8 also elaborated Yagya for long healthy life and cure of diseases (11). In addition to description regarding general health, Vedas also described mantras for the treatment of specificdiseases through Yagya Therapy, such as worm infections, fever, mania, goiter, etc. (Table 1, 2). For easy understanding, these diseases were divided into infectious (Table 1) and non-infectious (Table 2) diseases. General indications in the Vedics mantras (hymns) about the application of Yagya Therapy for these diseases have been described in Table 1 and 2 .

Vedas not only described physiological implications of Yagya Therapy, but they also illustrated the concept of complete health. For example, Yajurveda 30/1 described development of mental faculties such as mind, speech, and intellect through Yagya, while Yajurveda 18/2 described psycho-physiological benefit including Praan (vitality), chitta (subonsciousness), vani (speech), mana (mind), etc. through Yagya. In addition, Yajurveda $21 / 21$ and $12 / 19$ stated Yagya application to get peace and energy (11).

Precise details of the procedure of Yagya Therapy described in Vedas

In addition to the role of Yagya Therapy for attaining complete health, Vedic literature also provides details such as procedure of Yagya Therapy, performer eligibility, importance of herbal material, precautions, and supplements to be taken with application of Yagya Therapy. For instance, Chhandogya Upanishad 4/17/8 mentioned that Brahma (performer) of Bheshaj Yagya should be Aarogya-shashtra ka gyata (medical practitioner of Yagya Therapy) (12).

In Gopath Brahman 1/19, it is described that using herbs, seasonal yagya were performed during transitions of seasons, indicating Yagya was used to prevent and remove epidemic diseases, and to get health benefit for society (12).

\section{Mechanism of Yagya Therapy in Vedic literature} Vedas also mention the mechanism of Yagya Therapy. Rigveda 10/137/2-3 describes two ways for the transportation of the Yagya vayu (Yagya medicinalsmoke) in the human body. The inhaled medicinalsmoke is supposed to give immunity and strength, while exhaled breath provides removal of toxins out of the body. In addition, Rigveda 10/186/1-3 also describes that the breathing of Yagya vayu generated by the oblation of herbs in the fire is supposed to provide peace and happiness. It further stated that the Yagya vayu contained properties like nectar and provided longevity (10).

This mechanism of Yagya Therapy is also supported by recent findings, wherein positive impact of Yagya fumes on tuberculosis patients was observed (8). In addition, pharmacokinetic modeling and evaluation by Joshi et al. (13) showed that pulmonary inhalation of Yagya fumes significantly imparted higher bioavailability of phyto-medicines in blood, and provided higher lung deposits of phyto-medicines as compared to oral and intravenous administration of modern drugs (13).

General description of management of various diseases through Yagya Therapy (medicinal-smoke) in Ayurvedic literature

Medicinal-smoke of herbs for therapeutic purposes has been used globally. Practice of the inhalation of herbs through pulmonary route has prevailed in various cultures throughout the world. A study described use of fumes generated through mono or multi herbal preparation in 50 countries (14). 


\begin{tabular}{|c|c|c|}
\hline \multirow{4}{*}{$\begin{array}{l}\text { Tuberculosis } \\
\text { (T.B.) }\end{array}$} & $\begin{array}{l}\text { Atharvaveda } \\
3 / 11 / 1-2\end{array}$ & $\begin{array}{l}\text { Describes Yagya fire and Vayu (herbal smoke) to cure patient from expressed or } \\
\text { suppressed TB conditions, and even from last stage condition }\end{array}$ \\
\hline & $\begin{array}{l}\text { Atharvaveda } \\
3 / 11 / 3\end{array}$ & Describes Yagya fume to prevent TB recurrence \\
\hline & $\begin{array}{l}\text { Atharvaveda } \\
3 / 11 / 4\end{array}$ & $\begin{array}{l}\text { Describes Yagya's herbal fume along with Vayu, 'Yagya' Fire, Sun and Jupiter's vital force } \\
\text { (parjanya) to provide freedom from TB disease and to give longevity of } 100 \text { years }\end{array}$ \\
\hline & $\begin{array}{l}\text { Atharvaveda } \\
7 / 80 / 3-4 \\
7 / 81 / 1\end{array}$ & Describes Yagya to treat deep penetrated or primary infected TB disease \\
\hline \multirow{4}{*}{ Worm infections } & $\begin{array}{l}\text { Atharvaveda } \\
5 / 23\end{array}$ & Describes varieties of worms \\
\hline & $\begin{array}{l}\text { Atharvaveda } \\
1 / 8 / 1-4\end{array}$ & Describes 'Yagya' fume capability to destroy worms even in most hidden places \\
\hline & $\begin{array}{l}\text { Atharvaveda } \\
5 / 29 / 4\end{array}$ & Describes 'Yagya' fume to destroy worms through affecting their various functions \\
\hline & $\begin{array}{l}\text { Atharvaveda } \\
5 / 29 / 6-9\end{array}$ & $\begin{array}{l}\text { Describes 'Yagya' to destroy worms infecting the patients and their different routes of } \\
\text { entry; it also assures 'Yagya' to destroy both worms and their lineage (eggs) to make the } \\
\text { patient completely free from disease }\end{array}$ \\
\hline
\end{tabular}

Table 1. Yagya Therapy for non-infectious diseases mentioned in Vedic literature. Selected references regarding specific disease condition for which application of Yagya is described in Vedas are mentioned.

In Ayurveda, application of medicinal-smoke for therapeutic purposes has been discussed in detail. Charak Samhita 5/25-61 describes use of herbal smoking as a technique to cure or prevent diseases, which is similar to Yagya fume inhalation for treatment (5). In Ayurvedic texts (such as Bhaishajya Ratnavali, Yog-ratnakar), the inhalation of specific herbal medicinal-smoke (Dhoomapana) is recommended for therapeutic intervention for various conditions such as fever, pregnancy, poisonous animals' bites, etc. and for diseases such as mania, epilepsy, worm infections, syphilis, etc. The inhalation of medicinal-smoke of a specific herbal-powder combination of neem leaves (Melia azadirachta), bach (Acorus calamus), kooth (Saussurea lappa), harad (Terminalia chebula-Retz.), saraso (Brassica
campestris-Linn.) and googal (Commiphora mukulEngl.), destroys extreme fever in patients. In another example, the inhalation of the medicinal-smoke of a specific herbal-powder combination made using neem leaves, bach, hing (Ferula narthex-Boiss), sendha namak (Sodii chloridum), saraso was described to destroy worms, mange, and pus (2). 


\begin{tabular}{|c|c|c|}
\hline \multirow[t]{3}{*}{ Condition } & Vedic Mantra & Description \\
\hline & $\begin{array}{l}\text { Atharvaveda } \\
6 / 55 / 3\end{array}$ & Describes Yagya to prevent diseases \\
\hline & $\begin{array}{l}\text { Atharvaveda } \\
7 / 55 / 6\end{array}$ & Describes Yagya to provide longevity \\
\hline \multirow{6}{*}{$\begin{array}{l}\text { Diseases } \\
\text { without specific } \\
\text { description }\end{array}$} & $\begin{array}{l}\text { Atharvaveda } \\
7 / 89 / 1\end{array}$ & Describes Yagya to give strength \\
\hline & $\begin{array}{l}\text { Rigveda } \\
1 / 12 / 7\end{array}$ & Describes Yagya to destroy diseases \\
\hline & $\begin{array}{l}\text { Atharvaveda } \\
19 / 58 / 1\end{array}$ & $\begin{array}{l}\text { Describes Yagya to get longevity and vitality through burning of herbs with ghee for } \\
\text { long duration }\end{array}$ \\
\hline & $\begin{array}{l}\text { Rigveda } \\
3 / 10 / 3\end{array}$ & Describes Yagya to get strength through herbal sacrifice \\
\hline & $\begin{array}{l}\text { Atharvaveda } \\
1 / 12 / 2\end{array}$ & Describes Havi (herbal sacrifice) of 'Yagya' to resist fever and generated weakness \\
\hline & $\begin{array}{l}\text { Atharvaveda } \\
1 / 12 / 3\end{array}$ & $\begin{array}{l}\text { Describes Sun along with Havi will remove fever and associated symptoms like } \\
\text { headache, cough occurred through Vata, Pitta or Shleshma }\end{array}$ \\
\hline \multirow{2}{*}{ Fever } & $\begin{array}{l}\text { Atharvaveda } \\
5 / 22 / 1-2\end{array}$ & $\begin{array}{l}\text { Describes proper utilization of components of 'Yagya' such as Sun, Somras, Ved } \\
\text { and Kusha. Samidha, etc. will help remove fever and associated weakness }\end{array}$ \\
\hline & $\begin{array}{l}\text { Atharvaveda } \\
5 / 22 / 10 / 13\end{array}$ & $\begin{array}{l}\text { Describes Yagya to treat all types of fever such as cold, heat, long short, seasonal, } \\
\text { etc. }\end{array}$ \\
\hline Goiter & $\begin{array}{l}\text { Atharvaveda } \\
6 / 83 / 1-4\end{array}$ & $\begin{array}{l}\text { Describes intake of Yagya fumes along with Sun and moon rays to remove the } \\
\text { disease }\end{array}$ \\
\hline \multirow[t]{3}{*}{ Mania } & $\begin{array}{l}\text { Atharvaveda } \\
6 / 111 / 2\end{array}$ & $\begin{array}{l}\text { Describes Yagya fume to treat mania generated due to sin and patient having } \\
\text { uncontrolled speech. }\end{array}$ \\
\hline & $\begin{array}{l}\text { Atharvaveda } \\
20 / 16 / 11-13\end{array}$ & Describes Yagya to remove pregnancy associated problems and issues \\
\hline & $\begin{array}{l}\text { Rigveda } \\
10 / 162 / 1-2\end{array}$ & Describes Yagya to make embryo free from any foreign organism and worm \\
\hline \multicolumn{3}{|l|}{ Pregnancy } \\
\hline & $\begin{array}{l}\text { Rigveda } \\
10 / 162 / 3\end{array}$ & $\begin{array}{l}\text { Describes Yagya can manage condition such as impotency, abortion during fetus } \\
\text { development, unstable embryo, delivery risks and new born health issues }\end{array}$ \\
\hline & $\begin{array}{l}\text { Atharvaveda } \\
7 / 80 / 3-4,7 / 81 / 1\end{array}$ & Describes Yagya to treat deep penetrated or primary infected TB disease \\
\hline
\end{tabular}

Table 2: Yagya Therapy for non-infectious diseases mentioned in Vedic literature. Selected references regarding specific disease condition for which application of Yagya is described in Vedas are mentioned.

Precise details of the procedure and mechanism of Yagya Therapy (medicinal-smoke) described in Ayurvedic literature
In addition to this general indication, Ayurvedic texts describe the procedure and precautions in detail too. For instance, Charak Samhita 5/39-40, prescribes eight timings for taking medicinal-smoke, which are as follows: 1) after having bath, 2) after vaman (vomiting), 3) after taking food, 4) after sneezing, 5) after brushing the teeth, 6) after taking other types of nasya than dhoomnasya, 7) after taking anjan, and 8) after taking sleep. It further states that medicinal- 
fumes can balance vata and kafa, which frequently increase during these 8 times. Hence, it is advised to take medicinal fumes at these times. Besides these 8 times, other conditions where vata and kafa are increased and medicinal-smoke intake can provide benefit, are as follows: headache, disease related to sensory organs, migraine, hiccups, asthma, goiter, fungal infection, jaundice, cold, sneezing, insomnia, hair fall etc.

For precaution, Charak Samhita 5/41-45 states that medicinal-smoking is contraindicated in conditions such as pregnancy, exertion, hyper-mania, after taking milk and alcohol, head-injury, diphtheria, etc. $(2,5)$.

\section{Conclusion}

Vedic literature describes treatment of wide range of diseases (both infectious and non-infectious) and ailments through Yagya, along with the precautions, detailed procedures, causes of diseases, therapeutic supplements, etc. The present study presented a narrative literature review of the general management of various diseases through Yagya Therapy, as well as procedure and mechanism of Yagya Therapy, as mentioned in Vedic and Ayurvedic texts. Thus, this study will help in the establishment of Yagya Therapy as an important therapeutic approach, and will pave the way for further investigations in this field.

\section{References}

1. Brahmavarchas, editor. Hindu Dharm mein yagyon ka sthan tatha prayojan (Hindi). In: Yagya ka gyan-vigyan (Pt Shriram Sharma Achraya Vangmay No 25). Akhand Jyoti Sansthan, Mathura-281003; 1998. p. 2.67-2.71.

2. Brahmavarchas, editor. Yagyeeya Dhoomra kee upadeyataa evam mahatta (Hindi). In: Yagya- ek samagra upchar-prakriya. Mathura: Akhand Jyoti Sansthan, Mathura-281003; 1994. p. 1.161.20 .

3. Brahmavarchas, editor. Yagya se rog-nivaran evam balsamvarddhan ke do labh. In: Yagya- ek samagra upchar-prakriya (Pt Shriram Sharma Acharya Vangmay No 25) [Internet]. Akhand Jyoti Sansthan, Mathura-281003; 1994. p. 1-12.6. Available from: www.literature.awgp.org
4. Dwivedi R, Vishwakarma H, Dwiwedi UN. Atharvavediyaashtang-aayurved. In: Atharva-chikitsa-vijnana. Krishnadas Academy, Oriental Publishers \& Distributors, Post Bocx No. 1118 , Chowk, (Chitra Cinema Building), Varanasi-221001, India; 1984. p. 3-38.

5. Van Loon G, editor. Charaka Samhita Handbook on Ayurveda, volume II [Internet]. Vol. II, Charaka Samhita. 2002. 621 p. Available from:

http://www.rencapp.com/TamilCube_Charaka_Samhita.pdf

6. Sharma S. Yagya se sukh aur samruddhi ka bhautik vigyan. In: Yagya- ek samagra upchar-prakriya (Vangmay No 25). Akhand Jyoti Sansthan, Mathura - 281003; 1994. p. 1-12.6.

7. Brahmavarchas, editor. Yagyachikitsa-yagyopathy: ek samagra evam divya chikitsa paddhati (Hindi). In: Yagya Chikitsa. Shri Vedmata Gayatri Trust, Shantikunj, Haridwar (Uttarakhand), 249411, India; 2010. p. 15-35.

8. Raghuvanshi M, Pandya P, Joshi RR. Yagyopathic Herbal Treatment of Pulmonary Tuberculosis Symptoms: A Clinical Trial. Altern Complement Ther. 2004;10(2):101-5. Available from: http://www.liebertonline.com/doi/abs/10.1089/1076280047739333 52

9. Sharma S. Yagyopathy ek samagra chikitsa paddhati. In: Yagya- ek samagra upchar-prakriya. 2012th ed. Mathura: Akhand Jyoti Sansthan, Mathura - 281003; 1994. p. 3.18-3.27.

10. Sharma S, Sharma B devee, editors. Rigved samhita. Revision. Yug nirman yojana vistar trust, Gayatri Tapobhumi, Mathura-281003; 2013

11. Sharma S, Sharma B. Atharvaved Sanhita bhaag - 1. 2014th ed. Yug nirman yojana vistar trust, Gayatri Tapobhumi, Mathura; 1961.

12. Brahmavarchas, editor. Vedo me yagya chikitsa. In: Yagya ek samagra upchar-prakriya (Pt Shriram Sharma Acharya Vangmay No 26). Mathura: Akhand Jyoti Sansthan, Mathura-281003; 1994.

13. Joshi RR, Raghuvanshi M, Pandya P. Yagyopathy versus oral and iv drug administration: evaluation for pulmonary tuberculosis using compartment modeling. J Biol Syst. 2006;14(03):463-89. Available

from: http://www.worldscientific.com/doi/abs/10.1142/S0218339006001 891

14. Mohagheghzadeh A, Faridi P, Shams-Ardakani M, Ghasemi Y. Medicinal smokes. J Ethnopharmacol. 2006;108(2):161-84. 